\title{
Realizing Kampung Pelangi as a Sustainable Village City Using Asian New Urbanism: Ideological Approach
}

\author{
Leoni Dwi Agitha ${ }^{1, *}$, and Rina Kurniati ${ }^{2}$
}

\begin{abstract}
${ }^{1}$ Student of Urban and Regional Planning Department, Faculty of Engineering, Diponegoro University, Semarang - Indonesia ${ }^{2}$ Lecturer of Urban and Regional Planning Department, Faculty of Engineering, Diponegoro University, Semarang Indonesia
\end{abstract}

\begin{abstract}
Sustainable development is defined as fulfillment of the current needs without sacrificing the needs of future generations. This concept has long become the concern of experts until a goal of world development called Sustainable Development Goals/SDGs is born. Sustainable development have three pillars, namely economic, social and environment that integrated to achieve the method related to the condition of Kampung Pelangi. The analysis was using Doxiadis theory is reviewed by the Asian New Urbanism: Ideological Approach which is consisting of five planning instruments: Self Suffiency, Land as Resource, Shifting and Floating Values, Transport and Mobility, Conservation of Environmental. In the end there are several new program was initiated such as the implementation vertical garden using orchid, made the roadmap application to facilitate the tourist and increase community cooperation to improve the social economic life. The results of this research with the concept of Kampung Pelangi will be able to develop new programs based on sustainable development.
\end{abstract}

Keywords: Sustainable Development, Village City (Kampung Kota), Asian New Urbanism : Ideological Approach.

\section{Introduction}

The concept of sustainable development has long been the concern of experts. According to Brundlandt (1987, pp 8-9) [1], sustainable development is development in meeting the needs of the present without compromising the right to meet the needs of future generations. Agreeing with this, by 2015 the United Nations issues a world development goal called Sustainable Development Goals/SDGs. This goals have three pillars, namely economic, social and environmental, which requires them to be well integrated. The integration of these three aspects becomes a challenge to achieve a livable city. Many panning concepts are not able to provide balance to the three pillars, one of the development program of Wonosari Village become a tourist destination Kampung Pelangi.

The concept of Kampung Pelangi initially looks beautiful because every building is painted in color with interesting pictures. However, this concept is less in line with the principle of sustainability, painting the entire building is a short-term action. This is due to the absence of clarity of the program and the certainty of the fixed budget to continue the concept of sustainability. Therefore, the purpose of this study is to design a new based on characteristics analysis according to Doxiadis's theory [2] which is then reviewed through the approach of Asian New Urbanism: Ideological Approach. Asian New Urbanism : Ideological Approach is defined as a new urbanism movement that is at the level of ideological search for problems and potentials. According to Lim (1998, pp 228) [3], there are five planning instruments, namely Self Sufficiency, Land as Resource, Shifting and Floating Values, Transport and Mobility and Conservation of Environmental. Hopefully, this approachment could make Kampung Pelangi be a sustainable urban village.

\section{Methodology}

This research applied descriptive method by collecting data containing characteristics and nature of a phenomenon in Kampung Pelangi The data collection is done by surveying to see the physical condition of the area directly and interview the community to know the perspective view related to the social, cultural and economic aspects. After we get the data, we should analyze and interpret the results based on theories that used for the basis of this research. 


\section{Literature Review}

\subsection{Kampung Kota}

In the spatial dictionary, Kampung Kota is the part of the city that consist of housing groups with high population, lack of facilities and infrastructure, there are no obvious boundary, area coverage is larger than usually and the character is informal housing. According to Antony Sihombing [4] , Kampung Kota is defined as irregular, unstructure and informal settlements in the broader social-economic system. Kampung Kota can be seen as urban settlements that has a lack infrastructure, planning and urban networking. The worst, could create poverty and poor quality of life. Kampung Kota is a form of Indonesia indigenous settlement that brings the nature of rural life but still has irregular physical and environmental forms, building density accompanied by high population density and mixed land use pattern. Urban irregularity is usually synonymous with slums, but population density and mixed use can be an efficient alternative to land use. Certainly, it can be realized if there is good planning on the mix pattern of land use so Kampung Kota approachment could able to create the liveable and sustainable city.

\subsection{Sustainable City}

Sustainability is not only reducing the natural resources exploitation or maintaining environmental sustainability but to maintain the balance of social and economic system. Sustainable cities are a city that develops in an integrated, dynamic and balanced in environment, economic, socio-cultural and good governance. Based on Government Regulation number 26/2008 about National Spatial Planning, sustainable development has three dimensions. First, the sustainability of economic growth to involve the environment management that must be carried out effectively and efficiently with the principles of community, government and business. Second, sustainability of socio-cultural which are the values are formed to accordance with the role of the climate and stability political. Third, sustainability of environment (ecology) where the existence of harmony between human and ecosystem (natural environment and unnatural environment).

\subsection{Identification of Settlement Characteristics in Kampung Kota.}

Constantinos A. Doxiadis [2], argued the principle of settlement has five basic elements, namely the nature as land to reside, the man as personal or social beings, the society related to interaction and social relations between human, the shells are residence buildings and the networks as the means of infrastructure to support natural and unnatural environment. Based on the theory, the characteristics of slums can be identified as inhabitant, dwelling, facilities and infrastructure and environmental characteristics.
The four characteristics can be described as follows, first the characteristics of the inhabitants where is looking at the community social and economic conditions. These characteristics are identified based on the level of education, livelihood, population, density and level of public opinion. Second, the dwelling characteristics which are seen in the activity and social activities, the distortion occurs, the condition of residence buildings, the density and the community awareness to maintain the building. Third, the characteristics of facilities and infrastructure known as the availability to service management as a supporter the urban activities. Fourth, the environment characteristics which seen from the inside and outside activities that occur in neighborhood settlement.

\subsection{Asian New Urbanism : Ideological Approach}

Urbanisation could occur anywhere and anytime, unexpected levels of progress and related actors. Asian societies are confronted by issues such as cultural diversity, welfare, poverty, high population, increased economic growth and environmental degradation. Not only that, modernisation, globalisation and technological advances make the Asian community must adapt and filter as anticipation of global cultural flows The situation forms a crucial issue for urban dwellers that impact on sustainable urban development. Therefore, Lim [3] argued that the concept of Asian New Urbanism: Ideological Approach can be anticipated and criticized the modern planning process. This concept consists of five innovative instruments of planning, namely :

1. Self sufficiency, an effort to fulfill urban needs consisting of the production and reproduction process of the city itself, reducing dependence from the surrounding area, in particular in balancing the proportion of funding and urban service allocation

2. Land as Resource, a land use efforts by setting location, capacity, optimal intensity and control over development. Development is not always oriented in the city center but can also be at a point of growth that can be reached throughout the community.

3. Shifting and Floating Values, an efforts to prevent the expansion of the commercial sector location, preserve historic area and the placement of residential land in accordance with the needs of residents. It is oriented towards the theory of the value of land that is floating and placed at growth points.

4. Transport and Mobility, an effort to provide an affordable and reasonable mass transportation system that reduces pollution and environmental degradation of the city. Utilization of traditional facilities is still possible by regulating the hierarchy of ministry.

5. Conservation of Environmental Areas, an effort to conserve the buildings or historic areas by giving economic values. So could become the identity and has a strong role as one component of the city. 


\section{Result}

\subsection{Kampung Pelangi}

Kampung Pelangi is located at Wonosari Street III, Randusari Village, South Semarang Subdistrict, Semarang City, Central Java. Administratively, Kampung Pelangi has two hamlets $(R W)$, namely $R W$ III and $R W$ IV. The topography of the area is quite steep because it has a high and varied slopes. This resulted in the location between buildings become irregular, the absence of distance between buildings and border of the building so as to create a fairly solid impression. Initially, Kampung Pelangi is one of the slums area in Semarang City called Wonosari Village. But the concept of color in every wall of its building gives its own uniqueness, thus making this village as a tourist destination. Kampung Pelangi has social interaction by be done in the form of community gathering, between heads of hamlet and neighborhood, establishing communication between neighbors and children's and teenager's play activities.

\subsection{Analysis of Settlement Characteristics in Kampung Pelangi}

\subsubsection{Inhabitants Characteristic}

Kampung Pelangi has a high population density. This can be seen from the total population of approximately 3,000 people with an area of $40 \mathrm{Ha}$. The social character of the community is still very high where children and adolescents gather and play while adults and elderly are gathered to talk among neighbors or hold deliberations between neigbourhoods or hamlets. The level of education is good enough because almost the entire community has graduated from high school. While the economic condition of the community is still classified as downward because the average amount of community income is $\mathrm{Rp} 1,000,000.00$ - $\mathrm{Rp} 3,000,000.00$ per month. The livelihood of the community in the form of workers (civil servants or private), laborers, traders and drivers and with the concept of Kampung Pelangi tourism community has opened many shops or dining room for tourists.

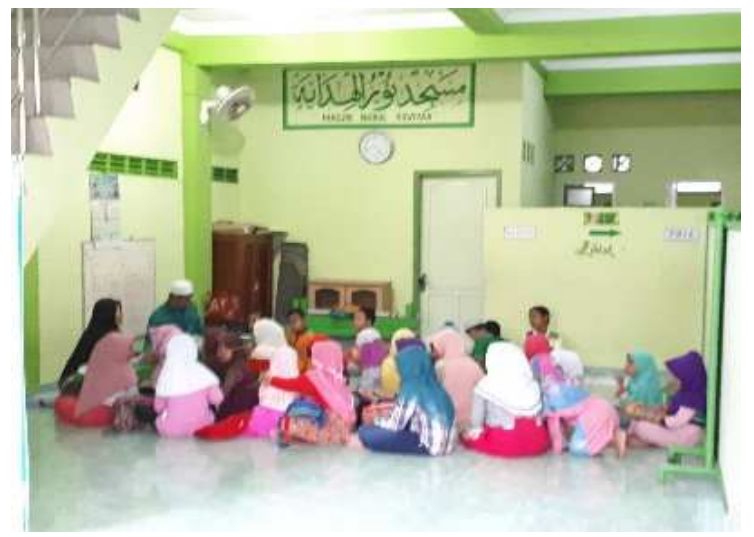

Fig. 1. Social Interactions Source : Author Survey, 2018

\subsubsection{Infrastructure and Facilities Characteristic}

Kampung Pelangi still has problems in the provision of facilities and infrastructure both in the number and condition. One example is a damaged in temporary dump sites that is not feasible to accommodate garbage but still used by the community. Availability of Facilities and Infrastructure in Kampung Pelangi can be seen in Table 1. Settlements that have become a tourist destination and give an impact on the development of public facilities and infrastructure. The government is improving the river in front of the village by building inspection and dredging rivers from garbage and mud. The government is also conducting the development of public space in the form of Kasmaran Park, parking lot, public toilets and food stalls in the hope that the tourism and social activities of Kampung Pelangi could be well supported.

Table 1. The Availability of Facilities and Infrastructure in Kampung Pelangi

\begin{tabular}{|c|c|c|c|}
\hline No & $\begin{array}{c}\text { Type of } \\
\text { Infrastructure }\end{array}$ & Infrastructure & Quantity \\
\hline \multirow[b]{2}{*}{1} & \multirow[b]{2}{*}{ Worship } & Mosque & 3 \\
\hline & & $\begin{array}{l}\text { Muslim Prayer } \\
\text { Romm }\end{array}$ & 3 \\
\hline \multirow{2}{*}{2} & \multirow{2}{*}{ Education } & Kindergarten & 1 \\
\hline & & Primary School & 1 \\
\hline \multirow[b]{2}{*}{3} & \multirow[b]{2}{*}{ Government } & Community Hall & 2 \\
\hline & & $\begin{array}{c}\text { Village Security } \\
\text { Post }\end{array}$ & 2 \\
\hline 4. & Health & $\begin{array}{c}\text { Center for Pre-and } \\
\text { ostnatal Health } \\
\text { Care }\end{array}$ & 2 \\
\hline 5 & Sport & Sporty Field & 1 \\
\hline 6 & Bussiness & Small Shop & 60 \\
\hline 7 & Garbage & $\begin{array}{c}\text { Temporary Dump } \\
\text { Sites } \\
\end{array}$ & 3 \\
\hline 8 & $\begin{array}{c}\text { Green Public } \\
\text { Space }\end{array}$ & Park & 1 \\
\hline 9 & Transportation & Bus Stop & 1 \\
\hline
\end{tabular}

Source : Kampung Pelangi Kalisari-Semarang, Perumaham \& Permukiman Sederhana Berbasis Kampung Wisata dan Kreativitas Karya

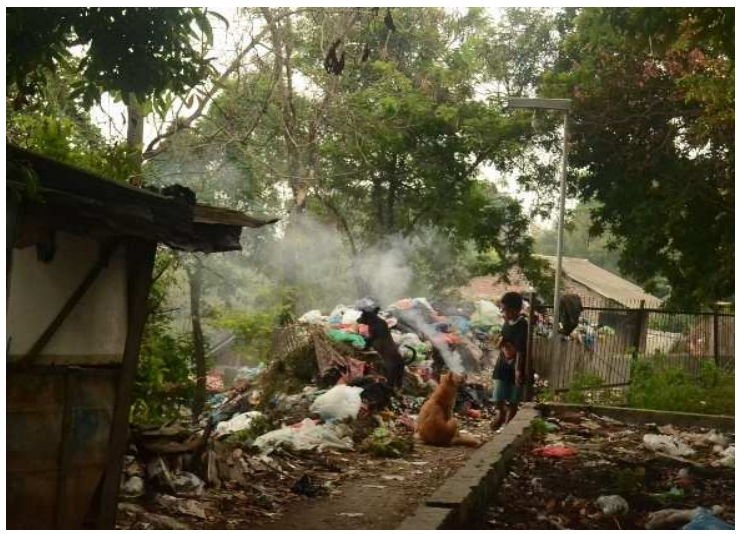

Fig. 2. Temporary Dump Sites Source : Author Survey, 2018 


\subsubsection{Shelter Characteristic}

The house has not been able to provide comfort because of the location is quite close and dense. The density is very high due to the lack of distance between buildings and there is no separation between private and public space. The concept of Kampung Pelangi makes the walls of every house painted colorful with interesting paintings. However, the building maintenance and preservation are still less because the color in the building is fading so it requires repainting.

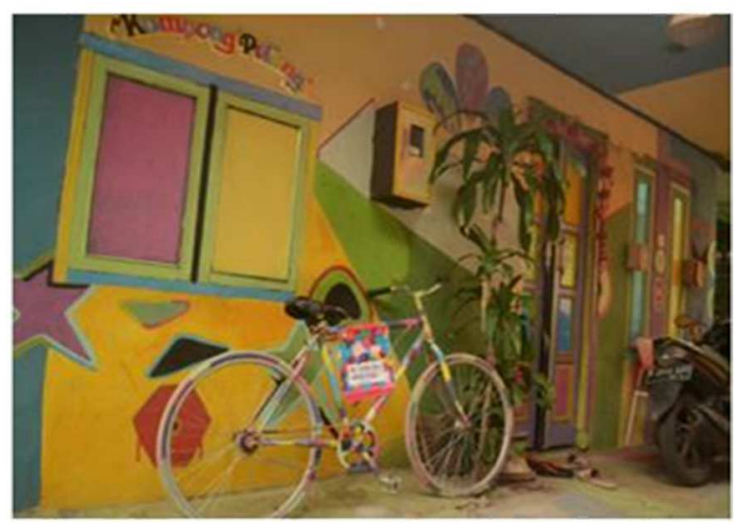

Fig. 3. The Shelter Condition in Kampung Pelangi Source : Author Survey, 2018

\subsubsection{Environmental Characteristic}

Analysis of environmental conditions can be seen from two aspects, consist of social and natural aspects. Social aspects could be seen from community interaction form community groups, like Pokdarwis (Kelompok Sadar Wisata/Tourism Awereness Raising Grop), Karang Taruna (Neighborhood Youth Association) and PKK (Pembinaan Kesejahteraan Keluarga/Family Welfare Program). While the natural aspects in the inside village is clean enough and there is a public park, namely Kasmaran Park. But this is inversely proportional because of the outside village did not has a garbage to provide Kalisari Flower Market.

\subsection{Applying the Asian New Urbanism Approach: Ecological Approach to the Kampung Pelangi Development}

Based on the analysis of settlement characteristics, Kampung Pelangi is still needs development to make it as a sustainable urban village. The main problems that are found are the lack of green area, innovation to develop Kampung Pelangi as tourism destination and low economic level. Therefore, there are several development programs based on the concept of Asian New Urbanism: Ideological Approach, namely the application of vertical garden using orchid plants, the development of the $N y i$ Brintik Tomb, the making of roadmap application and the improvement of community cooperation with the spirit of gotong royong (cooperation or sharing burden). The following is a program development outline based on five instruments of planning approaches Asian New Urbanism: Ideological Approach.

\subsubsection{Self Sufficiency}

Implementation of Self Sufficiency could be done with vertical orchid gardens program to increase communities economy from the sale income and the tourism attractiveness by creating a good photographing spots. The realization of this program in the form of orchid aid at the beginning of the plan so it can be sold so that income is reused to buy new orchid plants. The location of Kampung Pelangi that in the city center could be creating conformity from the benefits provided by orchid plants, which is able to eliminate pollution to create a clean, healthy and comfortable environment. Great hope, this program could create a new tourist attraction so as to establish a linkage location between the Kalisari Flower Market with Kampung Pelangi.

\subsubsection{Shifting and Floating Values}

Application of Shifting and Floating Values is the preservation of the historical grave of Nyi Brintik located in the upper region. The existence of Nyi Brintik Tomb should be able to serve as a tourist attraction for Kampung Pelangi tourism destination not only take pictures and see the sights but can do religious tours in the city center. The development program of Kampung Pelangi as a tourism destination with vertical garden is not enough to increase the cultural and historical value of Kampung Pelangi. Therefore, the program is created making history information boards Nyi Brintik Tomb and making a roadmap application that can be downloaded. The information boards are placed at the entrance and the roadmap application are contains of route roads, cafe/restaurants, photographing spots and the location of Nyi Brintik Tomb so could provide a convenience to the Kampung Pelangi tourists.

\subsubsection{Transport and Mobility}

Implementation of Transport and Mobility is the community cooperation to arrange the parking system and to utilize the bus stop so providing regularity and comfort to the community and the tourists. This program is an effort to increase the use of affordable mass transportation to reduce air pollution. The integrated and centralized parking arrangement system is conducted in Kasmaran Park, thus could be overcome parking problems, unlicensed use of space and vehicles theft. This is also supported by establishing regulations where the vehicles of tourists are not allowed to enter the village. Of course, a central integrated parking program creates jobs and become an community income While the utilization of bus stop could provide convenience for tourists who do not have a private vehicle and a liaison between the city center with Kampung Pelangi.

\subsubsection{Conservation of Environmental Areas}

Kampung Pelangi development program with vertical gardens concept is the application of Conservation of Environmental Areas planning instrument. Limited land and dense population become a problem in building the 
greening area. However, with the concept of this vertical gardens community needs for green areas can be met. The sustainability of vertical gardens program using orchids requires community cooperation with the principle of mutual assistance. In Indonesia, the community cooperation is known as gotong royong (cooperation or sharing burden) terminology. According to Rahmi, Wibisono, Setiawan, [5] gotong royong could help Kampung Kota to sustain the pressure from urbanization and un-equality of urban areas. The form of cooperation is to exchange ideas and consumers in the orchid sales activities and awareness together to take care the orchid plants.

\subsubsection{Land as Resource}

The concept of vertical garden as the fulfillment of the need of reforestation area is one of the application of Land as Resource planning instrument. Application of the concept of vertical garden does not require extensive land because the plants simply stick to the walls, tree trunks or depend on the home residents. Therefore, the density and lack of land is not a problem for the fulfillment of the greening area because the community is easy to find and choose the location to grow orchids. This concept is expected to ensure sustainability in environmental aspects so as to create harmony between urban activity with the environment.

\section{Conclusion and Recomendation}

\subsection{Conclusion}

The development of sustainability principle in Kampung Pelangi is expected not only to highlight the concept of colorful buildings but could able to build synergies between economic, social and environmental aspects. Based on the analysis of area characteristics according to Doxiadis, there are four programs based on the approach of Asian New Urbanism: Ideological Approach. First, self sufficiency with the application of vertical garden using orchids to enhance the tourist attraction and the community economy. Secondly, shifting and floating values with the history information boards of Nyi Brintik Tomb to preserve historic buildings and making roadmap applications to facilitate the tourists. Third, transport and mobility with the program of increasing community cooperation in the integrated and centralized parking system and the utilization of bus stops. Fourth, the conversation of enviromental areas with the program of increasing community cooperation with the principle of mutual assistance in selling and maintaining orchids to improve the economy. Fifth, land as resource with vertical garden to fulfill the green area in order to create harmony with the environment.

\subsection{Recomendation}

The new program will not be realized if there is no cooperation between government, private and communites. However, seeing the concept of Kampung Pelangi that has not been able to guarantee the principle of sustainability, the Government of Semarang City and Central Java Provincial Government are expected to be more critical in the implementation of the program, especially the programs that have been prepared. While the private sector and the community must be actively involved in creating and innovating developing the village. Moreover, because the program is based on the approach of Asian New Urbanism: Ideological Approach, the community cooperation based on mutual cooperation is the main basis in making Kampung Pelangi a sustainable urban village.

\section{References}

1. Brundtland, Gro. Report of the World Commission on Environment and Development: Our Common Future. (United Nations, 1987)

2. Doxiadis, Constantinos. Ekistics : An Introduction to The Science of Human Settlements. (Hutchinson of London, 1970)

3. Lim, William. Asian New Urbanism. (Select Books, 1998)

4. Sihombing, Antony. The Transformation Of Kampung Kota: Symbiosys Between Kampung And Kota, A Case Study From Jakarta. (Housing Authority, 2004)

5. Rahmi, D. H., Wibisono, B. H., \& Setiawan, B. Rukun and Gotong Royong : Managing Public Places in an Indonesian Kampung. In Pu Miao (Ed). Public Places in Asia Pacific Cities. (Kluwer Academic Publisher, 2001)

6. Makhmud, Desy, dkk. Mewujudkan Kampung Bandan Sebagai Kampung Kota Berkelanjutan Menggunakan Pendekatan Asian New Urbanism. (ResearchGate, 2017)

7. Nugroho, Agung. Kampung Kota Sebagai Sebuah Titik Tolak Dalam Membentuk Urbanitas Dan Ruang Kota Berkelanjutan. (Jurnal Rekayasa, 2009)

8. Nusyahbani, Raisya, dkk. Kajian Karakteristik Kawasan Pemukiman Kumuh Di Kampung Kota (Studi Kasus: Kampung Gandekan Semarang). (Jurnal Teknik PWK, 2015)

9. Rahman, Adi. Perubahan Budaya Bergotong Royong Masyarakat Di Desa Santan Tengah Kecamatan Marangkayu. (eJournal Sosiatri-Sosiologi, 2016) 